Research article

\title{
CLINICAL AND RADIOLOGICAL EVALUATION OF THE TREATMENT OF CRANIAL CRUCIATE LIGAMENT RUPTURE IN CATS WITH THE MUSCULUS BICEPS FEMORIS TRANSPOSITION TECHNIQUE
}

\author{
ŞEN İlker* \\ Cumhuriyet University, Faculty of Veterinary Medicine, Department of Surgery, Sivas / Turkey
}

(Received 01 April, Accepted 25 July 2019)

\begin{abstract}
The aim of this study was to clinically and radiologically evaluate the technique of biceps femoris muscle transposition as a new extracapsular treatment technique for cranial cruciate ligament ruptures, which are often encountered in cats. In this study, eight cats diagnosed with cranial cruciate ligament rupture were treated with the biceps femoris muscle transposition technique. The postoperative standard clinical examination procedures were applied to each cat for 90 days. In the preoperative clinical and radiological examinations of the eight cats in the study, cranial cruciate ligament rupture alone was diagnosed in seven of them. Both, the cranial cruciate ligament rupture and meniscal lesions in the same stifle joint were determined in one cat. The biceps femoris muscle transposition technique operation took approximately 20 mins in each case.

The postoperative radiographs were taken on days 10,30,60 and 90. No complications were seen in any case during the postoperative follow-up. The Illinois University Evaluation Scale was used for a more objective evaluation. At 90 days postoperatively, there was no lameness in seven out of eight cats, and mild limping was determined in one of them due to concomitant meniscal lesion.

According to the study results, the biceps femoris muscle transposition technique was found to be extremely useful as an easily applicable technique in the treatment of cranial cruciate ligament rupture in cats.
\end{abstract}

Key words: cat, cranial cruciate ligament, rupture, stifle joint, transposition, treatment.

\section{INTRODUCTION}

In comparison with dogs, there are extremely few studies related to cranial cruciate ligament (CCL) rupture in cats [1,2]. As lameness in cats seems to resolve without surgical intervention in the majority of cases, there is probably a low incidence of reported cases [2]. Just as CCL lesion may develop following trauma, it can also occur

*Corresponding author: e-mail: ilkersenn@yandex.com 
with normal weight-bearing as a result of progressive fatigue [3]. Although trauma is known to be the primary cause of CCL rupture in cats, it has been determined in recent studies that ruptures may occur as a result of degenerative deterioration in the mechanism of the cruciate ligament [2].

According to previous studies, trauma-related CCL rupture occurs in dogs at the rate of only $20 \%$. In the formation of the lesion, it has been reported that chronic degenerative arthritis plays a greater role in the lameness observed [4-8]. In contrast, most cases reported or describe it as a consequence of trauma in cats [1]. Excessive internal rotation, hyperextension of the stifle joint or abnormal loading on the ligament cause CCL rupture in cats $[9,10]$.

The effects of hormones and genetic factors on cruciate ligament ruptures in cats are not a subject that has been researched, but generally cats with CCL rupture are overweight cats [10].

The clinical symptoms that occur in cruciate ligament lesions include sudden onset of lameness and pain, joint effusion-hemarthrosis associated with acute joint inflammation, joint instability, and suspension of the relevant limb. When the animal uses the leg while walking, it is observed to take support from the tips of the paws and the stifle joint is bent more than necessary. Lameness may be observed at rest and can become worse with exercise $[11,12]$.

The diagnosis of cruciate ligament rupture in cats is made primarily on clinical results, physical examination and radiographs. In the physical examination, the cranial drawer test is positive. In addition, a positive tibial compression test, pain in the joint and the presence of effusion indicate CCL rupture. In chronic cases, a "click" sound in the joint on palpation and periarticular thickening might be observed. Joint instability is generally persistent in chronic cases. On the stifle joint radiographs, findings of osteoarthritis and effusion might be observed. In cats with CCL rupture, calcification or ossifications of the medial or lateral meniscus have been reported [10].

Treatment of the CCL ruptures can be conservative or surgical in cats [13]. In conservative treatment, restriction of movement, and when necessary, weight control are recommended. With this type of treatment, joint function and painfree range of motion are regained within nearly 4 months. However, in most cases treated conservatively, there can be persistent joint instability, a moderate degree of muscle dystrophy, thickening of the joint capsule and findings of moderate severity osteoarthritis [10].

Surgical treatment is applied to cats with persistent joint laxity and when there is no response to conservative treatment. When cats are reluctant to walk, surgical treatment can be applied at an earlier stage. Following preoperative evaluation, treatment of CCL rupture is applied with intracapsular and extracapsular techniques. Although innumerable techniques have been defined in the treatment of CCL rupture in dogs, extracapsular surgical techniques are more common in cats as they are less invasive than intracapsular methods, are simple to apply and less costly $[2,10]$. 
The aim of this study was to clinically and radiologically evaluate the application of the biceps femoris muscle transposition technique, as a new extracapsular treatment option in cats with cruciate ligament rupture in respect of functional healing of the related extremity and the elimination of joint instability.

\section{MATERIAL AND METHOD}

The study group was formed of eight cats of different breeds and ages that were diagnosed with CCL rupture upon clinical and radiological examinations.

Following clinical examination of each cat, preoperative radiological examination was applied. The Illinois University Scale was applied to each animal determined with CCL rupture for preoperative evaluation. The surgical procedure was performed then clinical and radiological follow-up examinations were made on postoperative days 10 , 30,60 and 90 .

\section{Surgical technique}

General anaesthesia was administered and the cat was positioned in lateral recumbecy with the affected extremity uppermost. Applying a cranio-lateral approach to the stifle joint, the incision line was extended from the distal third of the femur to the proximal third of the tibia. After dissection of subcutaneous tissue, the aponeurosis of the biceps femoris muscle was determined. Then, by separating this muscle insertion from the attachment area, an incision was made to the biceps femoris muscle from the junction site of the cranial margin of this muscle and the caudal margin of the vastus lateralis muscle, and a flap was prepared in a triangular shape by extending the incision by $1.5-2 \mathrm{~cm}$ in the same direction as the muscle fibrils from the caudal portion in the distal part of the biceps femoris.

With the stifle joint in extension, the prepared flap was transposed by being placed to the closest possible point of the attachment site of the tuberositas tibiae or ligamentum patella, and after fixation in this location, the tibia was moved first cranially then medially then distally [14]. The transposition flap was sutured to the relevant area with 2-0 polypropylene suture thread. Thus, in every contraction of the biceps femoris muscle, simulation of the CCL was provided (Figure 1, Figure 2).

After completion of the transposition, the cranialdrawer test was applied intraoperatively to each case. In cases where sufficient stability could not be obtained, the tension of the transposed flap was increased until the test was negative. Subcutaneous tissues and skin were routinely closed with sutures. Arthrotomy was not applied in any of the patients.

The operation area was protected with a soft bandage. The owners of the cats were informed that movement should be restricted for 15 days. 


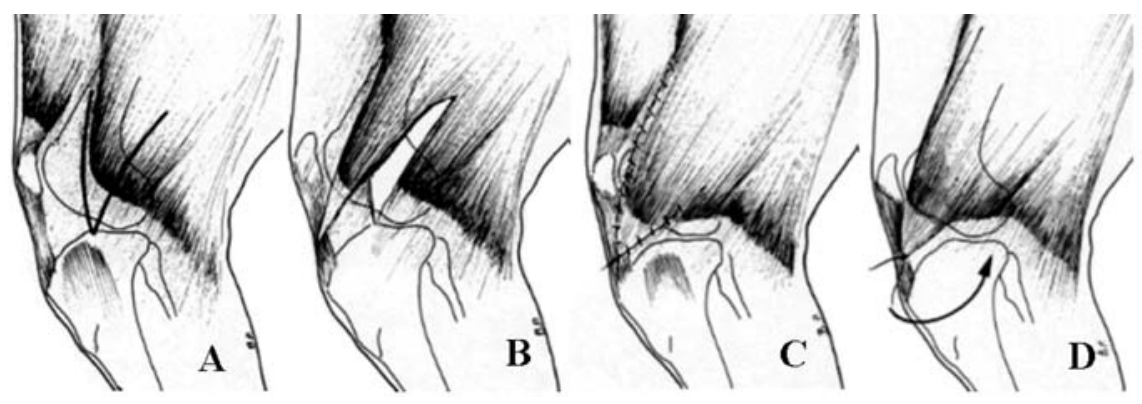

Figure 1. Transposition of the biceps femoris muscle. A) Identification of the aponeurosis of the biceps femoris muscle. B) The triangular-shaped flap prepared by separating the biceps femoris muscle from the insertion $\mathbf{C}$ ) Transposition of the prepared flap to the attachment area of the patella ligament to the tibial tuberosity. D) Prevention of cranial translation of the tibia with contraction of the biceps femoris muscle [14].

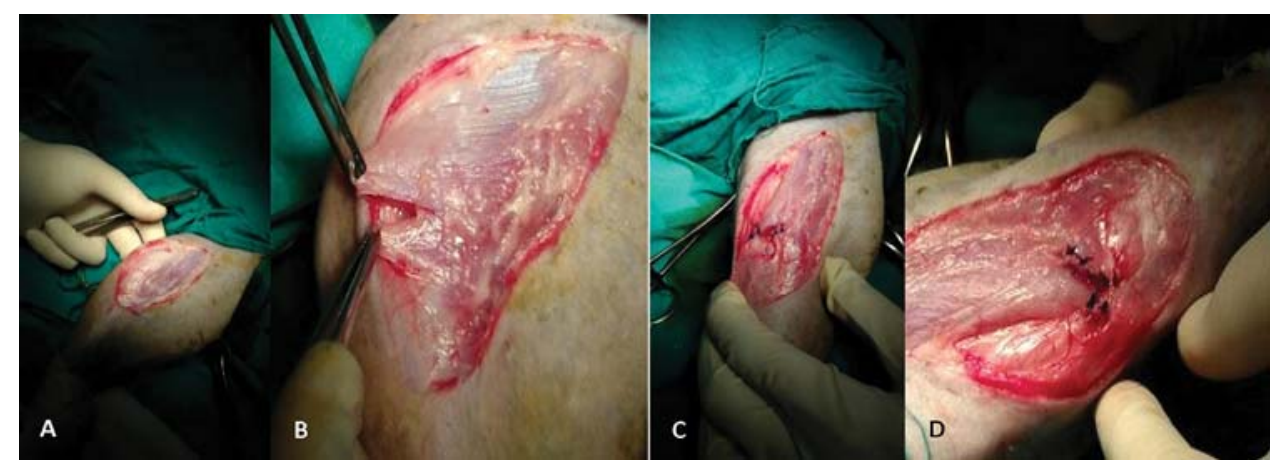

Figure 2. Stages of M. biceps femoris transposition. A) Identification of the biceps femoris muscle. B) Obtaining the triangular-shaped flap after identification. C) Lateral view of the transposition of the biceps femoris muscle to the tuberositas tibiae. D) Cranial view of the extremity applied with biceps femoris muscle transposition.

The owners were instructed to protect the operated extremity with a soft bandage (Robert-Jones) for 10 days.

On postoperative day 10, the bandage was removed, wound healing was checked and the sutures were removed.

The clinical findings obtained in the preoperative and postoperative periods were evaluated according to the Illinois University Evaluation Scale (Table 1). 
Table 1. Illinois University Evaluation Scale.

\begin{tabular}{|c|c|c|}
\hline \multirow{8}{*}{ 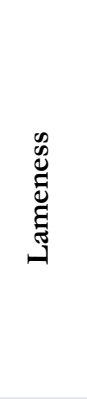 } & Degree & Assessment \\
\hline & 1 & Normal stance and gait \\
\hline & 1,5 & Normal stance and gait, mild lameness when stepping \\
\hline & 2 & Normal stance, mild lameness when walking \\
\hline & 2,5 & Slight deformity of stance, mild to maderate lameness when walking \\
\hline & 3 & Normal stance, severe lameness when walking \\
\hline & 3,5 & Deformity of stance, moderate lameness when walking \\
\hline & 4 & Deformity of stance, severe lameness when walking \\
\hline \multirow{5}{*}{ 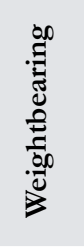 } & 1 & Normal stance and gait, normal weightbearing \\
\hline & 2 & Normal weightbearing in stance, slight pressure when walking \\
\hline & 3 & Abnormal weightbearing in stance, slight wightbearing when walking \\
\hline & 4 & Unequal weightbearing in stance, no using the extremity when walking \\
\hline & 5 & Never use the affected extremity (walking and stance) \\
\hline \multirow{6}{*}{ 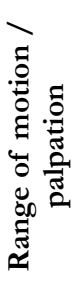 } & 1 & No limitation in range of motion, no crepitation \\
\hline & 1,5 & No limitation in range of motion, palpable crepitation \\
\hline & 2 & Mild limitation (10-20\%), no crepitation \\
\hline & 3 & Mild limitation (10-20\%), presence of crepitation \\
\hline & 4 & Moderate limitation, presence of crepitation \\
\hline & 5 & Severe limitation $(>50 \%)$, presence of crepitation \\
\hline \multirow{5}{*}{ 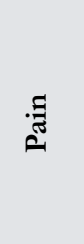 } & 1 & No pain on palpation of stifle joint \\
\hline & 2 & Mild pain on palpation of stifle joint \\
\hline & 3 & Moderate pain on palpation of stifle joint \\
\hline & 4 & Severe pain on palpation of stifle joint \\
\hline & 5 & Not allowed to palpation of stifle joint \\
\hline
\end{tabular}

\section{RESULTS}

The eight cats included in the study involved four males and four females, which were six cross-breeds, one Persian breed and one Ankara breed, with a mean age of 4 years (range 1-6 years) and mean weight of $4.4 \mathrm{~kg}$ (range, 3.2-6 kg). According to information given by the owners, the cause of the lesion was a fall from height in five cases and in three cases the cause was not known. The data related to the cases is shown in Table 2. 
Table 2. Data related to the breed, age, gender, weight and cause of the lesion of the cases

\begin{tabular}{|c|c|c|c|c|c|}
\hline Case No & Breed & Age & Gender & Weight & Reason of lesion \\
\hline 1 & Mix & 1 & $\sigma^{\pi}$ & 3,2 & High-rise \\
\hline 2 & Mix & 3 & $\sigma^{\pi}$ & 4 & High-rise \\
\hline 3 & Mix & 6 & 우 & 4,2 & Unknown \\
\hline 4 & Mix & 6 & ๙ & 5,3 & High-rise \\
\hline 5 & Mix & 4 & 우 & 6 & High-rise \\
\hline 6 & Persian & 2 & q & 3 & Unknown \\
\hline 7 & Mix & 5 & बे & 4,5 & Unknown \\
\hline 8 & Angora & 5 & 우 & 5,2 & High-rise \\
\hline
\end{tabular}

The eight cats were brought to the clinic with a complaint of not using the extremity and were determined with CCL rupture upon clinical and radiological examinations. The Illinois University Evaluation Scale was applied to all the cases in the preoperative period. According to this scale, defective standing and moderate limping while walking were determined in two cases (Case no 1 and 2), defective standing and severe lameness while walking in two cases (Case no 3 and 5), normal standing (equal weightbearing) and severe lameness while walking in one case (Case no 4), and normal standing and mild lameness while walking in three cases (Case no 6, 7 and 8).

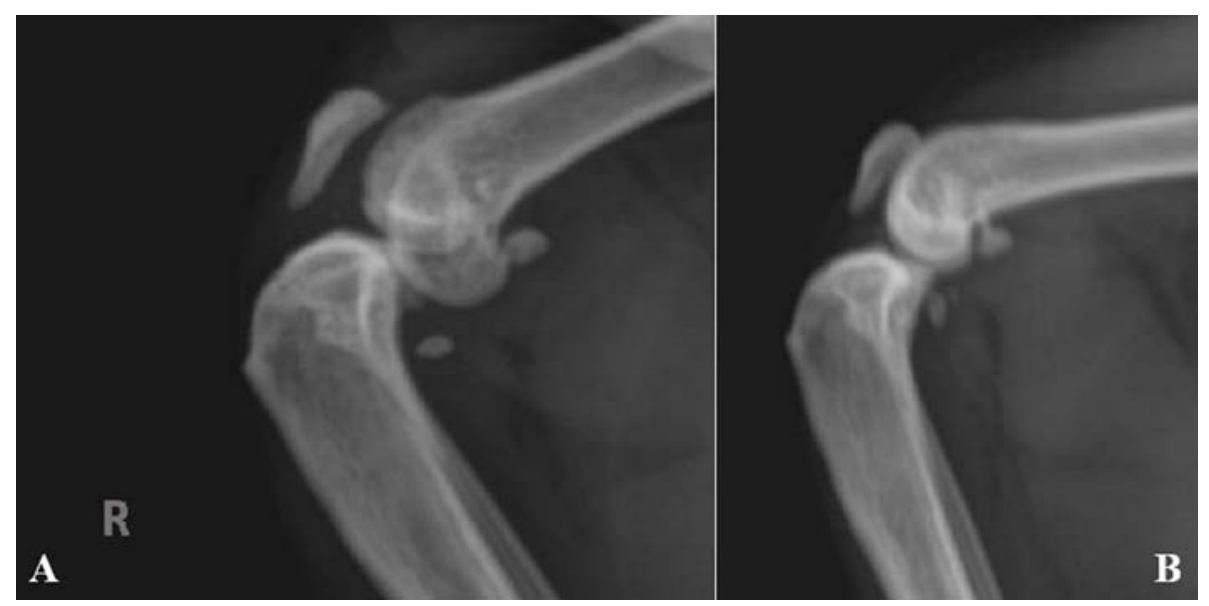

Figure 3. Radiographs of Case no 3. A) preoperative, B) postoperative $90^{\text {th }}$ day radiographs

In two cases (Case no 1 and 2), there was abnormal weightbearing when standing and slight weightbearing on the affected extremity when walking, in two cases (Case no 3 and 5) there was incomplete weightbearing when standing, and the affected extremity was not used when walking. In four cases (Case no 4, 6, 7 and 8), weightbearing on the affected extremity was normal when standing, and there was light stepping pressure when walking. 
In six out of the eight cats (Case no 1, 2, 5, 6, 7 and 8) there was no crepitation or restriction in joint range of motion, and in two cases (Case no 3 and 4), there was a mild (10\%-20\%) restriction in joint range of motion but no crepitation.

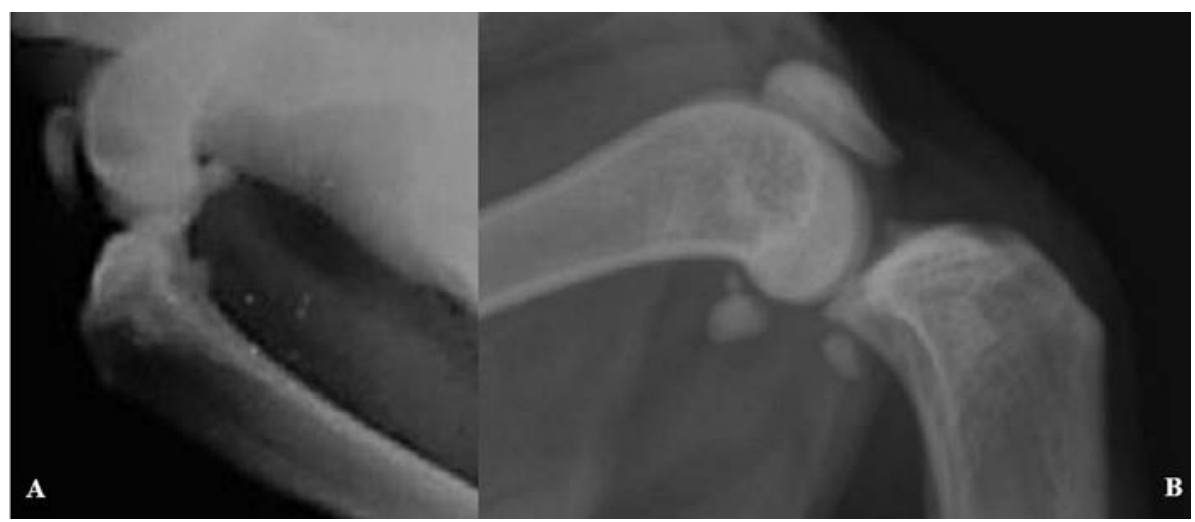

Figure 4. Radiographs of Case no 6. A) preoperative B) postoperative $90^{\text {th }}$ day radiographs

On palpation of the knee joint, mild pain was determined in three cases (Case no 1, 7 and 8), moderate pain in three cases (Case no 2, 3 and 4), severe pain in one case (Case no 5) and no evident pain in one case (Case no 6). The preoperative evaluation results of the cases according to the Illinois University Scale are shown in Table 3.

Table 3. The results of the evaluations made of the cases preoperatively and on postoperative days 10, 30, 60 and 90. A) Lameness, B) Weightbearing, C) Range of Motion / Palpation, D) Pain

\begin{tabular}{|c|c|c|c|c|c|c|c|c|c|c|c|c|c|c|c|c|c|c|c|c|}
\hline \multirow[b]{2}{*}{ Case } & \multicolumn{4}{|c|}{ Preoperative } & \multicolumn{4}{|c|}{ 10th day } & \multicolumn{4}{|c|}{ 30th day } & \multicolumn{4}{|c|}{ 60th day } & \multicolumn{4}{|c|}{ 90th day } \\
\hline & A & B & $\mathrm{C}$ & D & $\mathbf{A}$ & B & $\mathrm{C}$ & D & A & B & $\mathrm{C}$ & D & $\mathbf{A}$ & B & $\mathrm{C}$ & D & A & B & $\mathrm{C}$ & D \\
\hline 1 & 3,5 & 3 & 1 & 2 & 3 & 2 & 1 & 2 & 1 & 1 & 1 & 1 & 1 & 1 & 1 & 1 & 1 & 1 & 1 & 1 \\
\hline 2 & 3,5 & 3 & 1 & 3 & 3 & 2 & 1 & 2 & 1 & 1 & 1 & 1 & 1 & 1 & 1 & 1 & 1 & 1 & 1 & 1 \\
\hline 3 & 4 & 4 & 2 & 3 & 3,5 & 3 & 1 & 3 & 1 & 1 & 1 & 1 & 1 & 1 & 1 & 1 & 1 & 1 & 1 & 1 \\
\hline 4 & 3 & 2 & 2 & 3 & 3 & 2 & 2 & 1 & 1 & 1 & 2 & 1 & 1 & 1 & 1 & 1 & 1 & 1 & 1 & 1 \\
\hline 5 & 4 & 4 & 1 & 4 & 3,5 & 3 & 1 & 4 & 2,5 & 3 & 1 & 3 & 2 & 2 & 1 & 2 & 2 & 2 & 1 & 2 \\
\hline 6 & 2 & 2 & 1 & 1 & 1,5 & 2 & 1 & 1 & 1,5 & 1 & 1 & 1 & 1 & 1 & 1 & 1 & 1 & 1 & 1 & 1 \\
\hline 7 & 2 & 2 & 1 & 2 & 2 & 2 & 1 & 1 & 1 & 1 & 1 & 1 & 1 & 1 & 1 & 1 & 1 & 1 & 1 & 1 \\
\hline 8 & 2 & 2 & 1 & 2 & 1,5 & 2 & 1 & 1 & 1,5 & 1 & 1 & 1 & 1 & 1 & 1 & 1 & 1 & 1 & 1 & 1 \\
\hline
\end{tabular}

The biceps femoris transposition technique was applied to all the cases. The operating time for each case was approximately 20 mins. The Illinois University Evaluation Scale was applied to all the cases on postoperative days 10, 30,60 and 90. According to this scale on postoperative day 10, normal standing and severe lameness while walking were determined in three cases (Case no 1, 2 and 4), defective standing and moderate 
lameness while walking in two cases (Case no 3, 5), normal standing and walking with mild lameness when stepping in two cases (Case no 6 and 8), and normal standing and mild lameness while walking in one case (Case no 7).

In six cases (Case no 1, 2, 4, 6, 7 and 8), there was normal weightbearing when standing and light pressure when walking, in two cases (Case 3 and 5) there was abnormal weightbearing when standing, and light weightbearing when walking.

In seven cats (Case no 1, 2, 3, 5, 6, 7 and 8) there was no crepitation or restriction in joint range of motion, and in one case (Case no 4$)$, there was a mild (10\%-20\%) restriction in the joint range of motion, but no crepitation.

On palpation of the stifle joint, mild pain was determined in two cases (Case no 1 and 2 ), moderate pain in one case (Case no 3), severe pain in one case (Case no 5) and no evident pain in four cases (Case no 4, 6, 7 and 8).

The examinations on postoperative day 90 revealed clinical in seven out of the eight cats (Case no 1, 2, 3, 4, 6, 7 and 8) according to lameness, weightbearing on the affected extremity, range of motion, and pain on palpation. Case no 5 was determined with normal standing, mild lameness when walking, normal weightbearing on the extremity when standing, slight pressure when walking, restricted range of motion but no crepitation and mild pain on palpation of the stifle joint. These findings were associated with the presence of a meniscal lesion in addition to the CCL rupture.

The results of the evaluations of the cases made on postoperative days 10, 30, 60 and 90 are given in Table 3 .

\section{DISCUSSION}

The osteoarthritic changes in cats are variable and this process is seen at a lower rate than in dogs. However, the formation of osteophytes is seen in three months following an CCL lesion. These osteophytes are observed along the mediodorsal line of the tibia and the proximal patellar groove, starting from the proximal end of the patella [10]. In the radiographs taken of the eight cats in this study on postoperative days 10, 30, 60 and 90, and in the evaluations made throughout the follow-up period, no osteophyte formation or findings of osteoarthritis were observed.

The selection of which technique is to be used from surgical and conservative treatment options remains the preference of the surgeon. Clinical studies have determined that when extracapsular surgical techniques are used in the treatment of CCL rupture in cats, normal function of the affected extremity is regained within 2-4 weeks [10]. In the evaluation of the preoperative and postoperative findings in the current study, the Illinois University Evaluation Scale was used.

According to this scale, in the 4-week evaluation (30 days), case no 1, 2, 3, 4 and 7 were determined with normal standing and walking, in case no 5, there was mildly defective 
standing and mild-moderate lameness when walking, and in case no 6 and 8, standing and walking were normal with slight lameness when stepping.

Weightbearing on the extremities was equal and normal when standing and walking in cases $1,2,3,4,6,7$ and 8 , while in case no 5, there was observed to be mild weightbearing when standing and light stepping pressure when walking. There was no restriction in the range of motion or crepitation in cases $1,2,3,5,6,7$ and 8 , whereas case no 4 was observed to have mild (10\%-20\%) restriction in the range of motion and no findings of crepitation. On palpation of the stifle joint, there was no pain in cases $1,2,3,4,6,7$, and 8 , whereas case no 5 had a moderate level of pain. From these findings, it was seen that with the exception of case no 5 , clinical recovery had been obtained in all the other cases. These findings were consistent with data in the literature.

Despite developments in the treatment of CCL rupture in recent years, extracapsular techniques remain popular. Extracapsular techniques are applied to restore the functions and to stabilyse the stifle joint and to mimic the function of the CCL without making any anatomic changes to the bone structure of the stifle joint. These surgical procedures aim to restrict movement of the tibia in the cranial direction [15-17].

The main aim of the biceps femoris muscle transposition technique is to overcome laxity which is present in the joint in both the static and dynamic phases. The biceps femoris muscle transposition technique shows a double effect; in the static phase, it simulates the CCL direction, and in the dynamic phase, it provides joint stability with contraction of the biceps femoris muscle. In addition, the muscle pulls the tuberositas tibiae both externally and caudally, and thus the transposed muscle flap prevents cranial movement of the tibia and internal rotation.

The biceps femoris muscle transposition technique is the newest extracapsular treatment technique defined for application in the treatment of CCL rupture. In contrast to techniques including an osteotomy procedure, it is a much less invasive procedure as no osteotomy is applied. As the mean application time of this procedure was 20 mins, the intraoperative infection risk is minimal. There is no requirement for any implant for stabilisation as there is no osteotomy line in the bone tissue, and this significantly reduces the costs of the operation. A routine surgical set is sufficient in the application of the biceps femoris muscle transposition technique, which can be easily applied without the need for any extra set.

\section{CONCLUSION}

In this study, clinical and radiological evaluations were made of the biceps femoris muscle transposition technque and successful results were obtained in the treatment of CCL rupture in cats. This technique is a less invasive method than other treatment techniques. As the costs of the operation are extremely low and it can be applied more easily than other extracapsular techniques, this technique is more advantageous. 
The surgical procedure applied in this technique can be completed in a shorter time than other intra and extracapsular techniques. The mean application time of the biceps femoris muscle transposition technique has been reported as 20 minutes and in the current study the operations were completed in a similar time. Therefore, the risk of infection in the postoperative period can be considered to be extremely low compared to other surgical procedures.

As the data used for the evaluation of the study results are subjective, it is important that evaluation of study results is made using multimodal techniques in respect of obtaining more objective data.

Clinical and radiological evaluations were made in this study over a 90 -day period of the biceps femoris muscle transposition technique used in the treatment of eight cats with CCL rupture. When the results obtained are considered, it can be concluded that this technique can be used as an alternative treatment method to other intracapsular and extracapsular techniques.

\section{Authors' contributions}

The author performed literature searches, wrote, revised the article, read and approved the final manuscript.

\section{Declaration of conflicting interests}

The author(s) declared no potential conflicts of interest with respect to the research, authorship, and/or publication of this article.

\section{REFERENCES}

1. Harasen, GLG: Feline cranial cruciate rupture. Vet Comp Orthop Traumatol, 2005, 18(04): 254-257.

2. De Sousa RJR, Knudsen CS, Holmes MA, Langley-Hobbs SJ: Quasi-Isometric Points for the Technique of Lateral Suture Placement in the Feline Stifle Joint. Vet Surg 2014, 43(2):120-126.

3. Rooster HD, Bruin TD, Bree HV: Morphologic and Functional Features of the Canine Cruciate Ligaments. Vet Surg 2006, 35: 769-780.

4. Guthrie JW, Keeley BJ, Maddock E, Bright SR, May C: Effect of signalment on the presentation of canine patients suffering from cranial cruciate ligament disease. J Small Anim Prac 2012, 53: 273-277.

5. Hayashi K, Frank JD, Dubinsky C, Hao Z, Markel MD, Manley PA, Muir P: Histologic Changes in Ruptured Canine Cranial Cruciate Ligament. Vet Surg 2003, 32: 269-277.

6. Infernuso T, Loughin CA, Marino DJ, Umbaugh SE, Solt PS: Thermal Imaging of Normal and Cranial Cruciate Ligament-Deficient Stifles in Dogs. Vet Surg 2010, 39: 410-417 
7. Jerram RM, Walker AM: Cranial cruciate ligament ligament injury in the dog: pathophysiology, diagnosis and treatment. $\mathrm{N} Z$ Vet J 2003, 51: 149-158.

8. Kim SE, Pozzi A, Kowaleski MP, Lewis DD: Tibial osteotomies for cranial ligament insufficiency in dogs. Vet Surg 2008, 37: 111-125.

9. Dismukes DI, Tomlinson JL, Fox DB, Cook JL, Witsberger TH: Radiographic Measurement of Canine Tibial Angles in the Sagittal Plane. Vet Surg 2008, 37(3): 300-305.

10. Montavon MP, Voss K, Langley-Hobbs SJ: Feline Orthopedic Surgery and Musculoskeletal Disease. Philedelphia: Elsevier, 2009, 481-483.

11. Rooster HD, Ryssen BV, Bree HV: Diagnosis of cranial cruciate ligament injury in dogs by tibial compression radiography. Vet Rec 1998, 142: 366-368.

12. Slatter D: Stifle Joint. In: Textbook of Small Animal Surgery. Ed.: Vasseur PB. Volume II. 3rd Edition. Philadelphia: Elsevier, 2003, 2090-2118.

13. Tamburro R, Pinna S, Tribuiani AM, Panacea A, Carli F, Venturini A O. Biceps femoris muscle transposition for treatment of cranial cruciate ligament rupture in small breed dogs. J Vet Sci 2012, 13(1): 93-98.

14. Hoots EA, Petersen, SW: Tibial Plateau Leveling Osteotomy and Cranial Closing Wedge Ostectomy in a Cat With Cranial Cruciate Ligament Rupture. J Am Anim Hosp Assoc, 2005, 41(6), 395-399.

15. Conzemius MG, Evans RB, Besancon MF, Gordon WJ, Horstman CL, Hoefle WD, Nieves MA, Wagner SD: Effect of surgical technique on limb function after surgery for rupture of the cranial cruciate ligament in dogs. J Am Vet Med Assoc 2005, 226: 232-236.

16. Cook JL: Cranial cruciate ligament disease in dogs: biology versus biomechanics. Vet Surg 2010, 39: 270-277.

17. Kunkel KAR, Basinger RR, Suber JT, Gerard PD: Evaluation of a transcondylar toggle system for stabilization of the cranial cruciate deficient stifle in small dogs and cats. Vet Surg 2009, 38(8): 975-982.

\title{
KLINIČKA I RADIOLOŠKA PROCENA TRETMANA RUPTURE KRANIJALNOG KRUCIJALNOG LIGAMENTA MAČKE TEHNIKOM TRANSPOZICIJE MUSCULUS BICEPS FEMORIS
}

\author{
ŞEN İlker
}

Cilj ove studije je bio da se klinički i radiološki proceni tehnika transpozicije femoralnog bicepsa, kao nova ekstrakapsularna metoda tretmana rupture kranijalnog ukrštenog ligamenta mačaka. Navedenom metodom tokom ove studije tretirano je osam mačaka sa rupturom kranijalnog ukrštenog ligamenta. Standardni postoperativni protokol je primenjen kod svih osam tretiranih mačaka tokom narednih 90 dana nakon operacije. Tokom preoperativnih kliničkih i radioloških ispitivanja od osam ispitanih mačaka ruptura samo kranijalnog ukrštenog ligamenta je dijagnostikovana kod sedam mačaka. Od isptivanih životinja jedna mačka je pored rupture krucijalnog ligamenta 
na istom zglobu imala i lezije meniskusa. Hirurška intervencija transpozicije mišića biceps femoris-a je kod svakog pacijenta trajala u proseku 20 min.

Postoperativno radiografsko praćenje svakog pacijenta je bilo 10, 30, 60 i 90 dana nakon operacije. Tokom postoperativnog praćenja nisu uočene komplikacije.U cilju objektivne procene svakog pacijenta primenjena je Illinois University skala za evaluaciju. Nakon 90 og dana sedam mačaka nije pokazalo hromost ekstremiteta, dok je mačka koja je imala istovremeno i lezije meniskusa pokazala blagi stepen hromosti.

U skladu sa postignutim rezultatima, intervencija transpozicije mišića bicepsa butne kosti se pokazala kao pogodna metoda tretmana rupture kranijalnog ukrštenog ligamenta kod mačaka. 